CENDEKIA, Vol. 11, No. 2, Oktober 2017

p ISSN: 1978 2098; e ISSN: 2407 8557

Http://cendekia.pusatbahasa.or.id; Email: cendekiaoslo@gmail.com Center of Language and Culture Studies, Surakarta, Indonesia

Handayani, Sri. 2017. Listening Teams: Strategi Pemahaman Isi Teks

Pada Siswa SMPN 1 Karangploso. Cendekia, (2017), 11(2): 129 142.

\title{
LISTENING TEAMS: STRATEGI PEMAHAMAN ISI TEKS PADA SISWA SMPN 1 KARANGPLOSO
}

\author{
Sri Handayani \\ SMPN 1 Karangploso \\ Jalan PB. Sudirman 49 Karangploso, Kabupaten Malang
}

Email: srihandayani@gmail.com

\begin{abstract}
This study aims to improve the ability to understand the content of the text using listening strategy teams for seventh grade students of SMP Negeri 1 Karangploso. The design of this study was a two-cycle classroom action research assigning 34 students as research subject. The study revealed that the mastery learning to understand the text content increases in each cycle. Mastery learning was achieved by $17,86 \%$ of 34 students in the pre-cycle, $42.86 \%$ students in the cycle I, and $85.72 \%$ students in the cycle II. In the precycle, insufficient of the mastery learning achieved $82.14 \%, 57.14 \%$ in the cycle I, and $14.28 \%$ in the cycle II. This proves that the use of listening teams strategies successfully improved to understand the text coontents.
\end{abstract}

Keywords: understand the text, listening strategy teams, learning outcomes

Membaca merupakan salah satu keterampilan berbahasa. Menurut Tarigan (1990:7) membaca adalah salah satu proses yang dilakukan serta dipergunakan oleh pembaca untuk memperoleh pesan yang hendak disampaikan oleh penulis melalui media kata atau bahasa lisan. Berdasarkan pengertian tersebut, ada beberapa informasi (1) membaca bertujuan untuk memperoleh pesan, (2) membaca sebagai keterampilan perlu diasah dan dilakukan secara berkelanjutan, dan (3) membaca dilakukan untuk mendapat informasi. Hal ini menandakan bahwa membaca sangat penting bagi kehidupan.

Berdasarkan hasil studi "Most Littered Nation In the World" yang dilakukan oleh Central Connecticut State Univesity pada Maret 2016, Indonesia dinyatakan menduduki peringkat ke-60 dari 61 negara soal minat membaca. Indonesia persis berada di bawah Thailand (59) dan di atas Bostwana (61). Padahal, dari segi penilaian infrastuktur untuk mendukung membaca peringkat Indonesia berada di atas negaranegara Eropa (Kompas, 2016). Selain itu, survei UNESCO menyebutkan bahwa minat baca masyarakat Indonesia baru 0,001 persen. Artinya, dalam seribu masyarakat hanya ada satu masyarakat yang memiliki minat baca. Hal ini menunjukkan perlunya peningkatan minat baca masyarakat. Peningkatan tersebut dimulai dari peningkatan kemampuan membaca di tingkat sekolah.

Peningkatan membaca di sekolah dimulai dari memahamkan siswa terhadap isi teks. Hal ini sesuai dengan tujuan membaca secara umum antara lain (1) mendapatkan informasi, (2) memperoleh pemahaman, dan (3) memperoleh kesenangan. Secara khusus, tujuan membaca adalah (1) memperoleh informasi faktual, (2) memperoleh keterangan tentang sesuatu yang khusus dan problematis, (3) memberikan penilaian 
kritis terhadap karya tulis seseorang, (4) memperoleh kenikmatan emosi, dan (5) mengisi waktu luang (Nurhadi, 1987:11). Di dalam proses membaca, siswa harus merangkai kata demi kata, kalimat demi kalimat, dan paragraf demi paragraf kemudian menghubungkan hal yang dibaca dengan pengalaman yang dimiliki serta makna yang ditimbulkan sehingga siswa mampu memahami isi bacaan yang dibacanya.

Membaca untuk memahami isi bacaan merupakan bagian membaca pemahaman. Yasin (dalam Arthana, 1997:7) mendefinisikan membaca pemahaman sebagai suatu perbuatan yang dilakukan berdasarkan kerjasama beberapa kemampuan yaitu mengamati, memahami, dan sekaligus memikirkan isi bacaan. Dalam memahami isi bacaan secara konstruktif, pembaca menggunakan skematanya untuk membangun makna sutau teks. Dalam hal ini, pembaca mengandalkan semua pengetahuan yang telah dimiliki sebelumnya. Pemahaman isi teks berkaitan dengan kegiatan siswa membaca, menjawab pertanyaan, memaknai beberapa kata dalam kalimat, dan menyimpulkan isi teks. Proses membaca memerlukan fokus siswa untuk mencerna kata demi kata. Hasil membaca adalah komunikasi dari pemikiran dan emosi antara penulis dengan pembaca. Komunikasi tersebut terjadi dari konstruksi pembaca melalui integrasi pengetahuan yang telah dimiliki pembaca dengan informasi yang disajikan dalam teks. Komunikasi dalam membaca bergantung pada pemahaman yang dipengaruhi seluruh aspek membaca. Kegiatan menjawab pertanyaan dilakukan dengan menjawab beberapa pertanyaan terkait isi teks. Kegiatan memaknai kata dilakukan dengan mencari kata atau istilah sulit berdasarkan kamus. Kegiatan menyimpulkan isi teks dilakukan siswa setelah melalui serangkaian kegiatan lainnya untuk menemukan inti sari bacaan.

Membaca adalah sebuah proses yang kompleks, artinya dalam proses membaca terlibat sebagai faktor internal dan faktor eksternal pembaca. Faktor internal dapat berupa intelegensi (IQ), minat, sikaf, bakat, motivasi tujuan membaca, teks bacaan (sederhana-berat, mudah-sulit). Faktor eksternal dapat pula dikatakan faktor lingkungan atau faktor latar belakang, sosial ekonomi, kebiasaan, dan tradisi membaca (Nurhadi, 1987:13). Salah satu faktor penunjang minat baca siswa yaitu motivasi membaca. Oleh karena itu, guru perlu menemukan formula yang tepat untuk memotivasi siswa agar suka membaca.

Motivasi belajar memengaruhi hasil belajar siswa. Pengaruh tersebut diperlihatkan pada perubahan tingkah laku siswa. Hamalik (2002) mengungkapkan bahwa belajar adalah perubahan tingkah laku yang berkaitan dengan latihan dan pengalaman. Perubahan tersebut mencakup tiga ranah di antaranya (1) kemampuan kognitif yaitu kemampuan dalam pemahaman dan penguasaan ilmu pengetahuan yang dipelajari, (2) kemampuan sensorik psikomotorik merupakan ketrampilan atau kecakapan dalam mengerjakan tugas atau mempraktikkan suatu materi pelajaran, (3) kemampuan dinamik efektif adalah sikap maupun perilaku yang menunjukkan perubahan. Seiring proses belajar mengajar, siswa mendapatkan 'sesuatu' yang berguna bagi dirinya.

Hasil belajar digunakan sebagai salah satu penentu keberhasilan pembelajaran. Menurut Sudjana (2005) hasil belajar adalah hasil yang diperoleh dari proses pemberian nilai terhadap pengalaman belajar, dan penilaian terhadap hasil belajar diukur melalui norma, patokan, maupun kriteria tertentu. Proses penilaian tersebut disesuaikan dengan keaktifan siswa selama proses pembelajaran dan hasil tes. 
Dalam pembelajaran bahasa Inggris, siswa dikenalkan pada pola yang berbeda dengan bahasa Indonesia. Salah satu contohnya ketika mengatakan kegiatan yang sudah terjadi sebelumnya, terdapat kata kerja yang harus diubah bentuknya. Ketika memanggil seseorang dengan sebutan 'bu' harus melihat apakah si ibu berstatus menikah atau belum menikah. Hal ini dikarenakan terdapat pembedaan antara miss dan mrs. Ketika menyatakan suatu benda yang banyak, maka kata benda diberi akhiran $-s$ atau -es. Semenra itu, dalam bahasa Indonesia pola tersebut tidak ada. Oleh karena itu, guru perlu memberi beberapa catatan sehingga siswa mampu mengingat pola-pola dalam bahasa Inggris.

Berdasarkan hasil pengamatan yang dilakukan peneliti tanggal 14 September 2015 pada 34 siswa kelas VIIA tahun pelajaran 2015/2016 di SMP Negeri 1 Karangploso, ditemukan $85 \%$ siswa belum mampu mengelola bahasa tulis menggunakan pola bahasa Inggris yang benar. Hal ini dapat dilihat dari hasil siswa ketika diberi tugas membaca teks dan menjawab pertanyaan berdasarkan isi teks. Ternyata, hanya $37 \%$ siswa yang berhasil menjawab isi teks sesuai dengan pola kalimat bahasa Inggris, sedangkan $63 \%$ lainnya hanya mampu menjawab menggunakan katakata singkat (langsung menuju pokok pertanyaan). Rata-rata siswa mengalami kesalahan tiga-lima penggunaan kata benda. Berdasarkan tes, hasil siswa menunjukkan rata-rata kelas 69,27. Padahal, kriteria ketuntasan minimal (KKM) adalah 75. Kesalahan lain yang dilakukan siswa yaitu pola penulisan kalimat masa lalu, sekarang, dan masa mendatang. Ketidakmampuan siswa dalam membedakan beragam teks tersebut dapat menghambat hasil belajar. Ketika siswa tidak bisa membedakan grammar, verbs, maupun dictions yang digunakan dalam suatu teks, maka proses pembelajaran berbasis teks tidak akan berhasil.

Untuk meningkatkan motivasi dan hasil belajar siswa, peneliti menggunakan strategi listening teams. Penggunaan strategi listening teams diharapkan dapat membantu siswa dalam memahami isi bacaan secara bertahap. Strategi listening teams dipilih dalam pembelajaran memahami isi teks dengan harapan dapat membantu meningkatkan kemampuan pemahaman dan konsentrasi siswa. Menurut Zaini (2011:30) strategi listening teams bertujuan membantu siswa untuk tetap konsentrasi dan fokus dalam pelajaran. Pembelajaran listening team, siswa dituntut untuk bertanggung jawab terhadap tugas dalam kelompok dan membuat siswa lebih termotivasi mencari jawaban yang benar untuk memecahkan masalah dan mencari cara untuk menuntaskan kegiatan belajar. Jika kegiatan belajar berlangsung dengan aktif, maka akan berpengaruh terhadap pemahaman siswa. Strategi listening teams merupakan strategi di mana siswa dibentuk menjadi empat kelompok yang mempunyai tugas atau tanggung jawab tertentu. Kelebihan strategi listening teams dalam pembelajaran yaitu dapat menimbulkan persaingan sehat antartim untuk mengungkapkan gagasan yang ada dalam pikiran mereka.

Penelitian ini juga didasarkan pada hasil penelitian Lubis (2010) yang menyimpulkan bahwa model pembelajaran kooperatif listening team dapat mempengaruhi pemahaman siswa. Hal ini dibuktikan dengan hasil belajar siswa kelas eksperimen lebih tinggi dibanding kelas kontrol, yaitu rata-rata hasil belajar siswa pada kelas eksperimen sebesar 75,51 lebih tinggi dibandingkan hasil belajar siswa pada kelas kontrol, yaitu sebesar 68,51. Berdasarkan analisis uji t diketahui thitung atau to $=2,975$ 
lebih besar dari ttabel pada taraf signifikan 5\% $(2,975>2,000)$, ini berarti ada perbedaan yang signifikan pemahaman siswa pada mata pelajaran ekonomi antara siswa kelas yang menerapkan model pembelajaran listening team dengan kelas yang tidak menerapkan pembelajaran listening team di SMAN 1 Kecamatan Kuantan Hilir Kabupaten Kuantan Singingi. Dengan adanya perbedaan tersebut berarti ada pengaruh yang signifikan penerapan model pembelajaran listening team terhadap pemahaman siswa pada mata pelajaran ekonomi di SMAN 1 Kecamatan Kuantan Hilir Kabupaten Kuantan Singingi.

Penelitian Yunita (2013) menyimpulkan bahwa peningkatan kemampuan mendengarkan berita menggunakan strategi listening teams bisa dilihat melalui skor rata-rata kelas mulai dari kegiatan pratindakan hingga siklus kedua. Pada kegiatan pratindakan skor rata-rata kelas yang didapat sebesar 42,23. Pada siklus pertama skor rata-rata kelas meningkat menjadi 59,2 dan pada siklus kedua kembali meningkat menjadi 72,93 dari skor rata-rata kelas siklus pertama. Berdasarkan perolehan skor ratarata kelas di atas, disimpulkan bahwa mulai dari kegiatan pratindakan hingga siklus kedua terjadi peningkatan skor rata-rata kelas sebesar 30,7.

Persamaan penelitian Lubis dengan penelitian ini yaitu strategi pembelajaran listening teams yang digunakan. Perbedaan terletak pada rangangan penelitian. Penelitian ini menggunakan rancangan penelitian tindakan kelas, sedangkan penelitian Lubis merupakan penelitian eksperimen. Selain itu, penelitian ini diterapkan pada mata pelajaran bahasa Inggris, sedangkan penelitian Lubis diterapkan pada mata pelajaran ekonomi. Persamaan penelitian Yunita dengan penelitian ini yaitu penggunaan rancangan penelitian tindakan kelas dan penggunaan strategi listening teams. Perbedaan terletak pada materi pembelajaran dan mata pelajaran, penelitian Yunita digunakan pada mata pelajaran bahasa Indonesia, sedangkan penelitian ini diterapkan pada mata pelajaran bahasa Inggris.

Berdasarkan uraian tersebut, maka peneliti melakukan penelitian tindakan kelas dengan memanfaatkan strategi listening teams untuk memahami isi teks dengan judul "Peningkatan Motivasi dan Hasil Belajar Bahasa Inggris Menggunakan Metode Pembelajaran Berbasis Teks pada Siswa Kelas VII Tahun Pelajaran 2015/2016”.

\section{METODE}

Pendekatan penelitian ini merupakan penelitian tindakan kelas (classroom action research). Penelitian ini dirancang dalam dua siklus. Setiap siklus terdiri dari empat tahapan, yaitu: perencanaan tindakan, pelaksanaan tindakan, observasi/evaluasi, dan refleksi (Kemmis dan Mc. Taggart, 1998). Pada penelitian kualitatif, peneliti sendiri atau dengan bantuan orang lain merupakan alat pengumpul data utama (Moleong, 2007:9). Peneliti berperan sebagai perencana, pelaksana, pengumpul data, penganalisis data, penafsir data, dan pada akhirnya peneliti menjadi pelapor hasil penelitian. Penelitian ini dilakukan di SMP Negeri 1 Karangploso. Subjek penelitian yaitu siswa kelas VIIA SMP N 1 Karangploso tahun pelajaran 2015/2016 sebanyak 34 siswa, 17 perempuan dan 17 laki-laki. Penelitian dilakukan dimulai dari bulan September 2016 hingga November 2016.

Data yang dikumpulkan dalam penelitian ini berupa (1) hasil observasi selama proses pembelajaran yang berpedoman pada lembar observasi, (2) hasil tes yang dilaksanakan pada akhir siklus, (3) dokumentasi berupa foto-foto aktivitas guru dan 
siswa selama proses pembelajaran berlangsung. Perangkat pembelajaran yang digunakan adalah RPP dan lembar kerja siswa. Data hasil observasi yang dilakukan dianalisis dengan memberikan skor untuk penentuan kategori.

Indikator keberhasilan dalam penelitian ini yaitu meningkatnya hasil belajar siswa kelas VIIA SMPN 1 Karangploso tahun pelajaran 2015/2016 pada materi monolog descriptive sederhana. Peningkatan tersebut ditandai dengan rata-rata hasil belajar siswa $\geq 80$, dengan ketuntasan belajar $\geq 75 \%$ dari jumlah seluruh siswa.

Data hasil observasi yang dilakukan dianalisis dengan memberikan skor untuk penentuan kategori.

\section{Persentase keberhasilan $=\frac{\sum \text { Deskriptor yang muncul } X 100 \%}{\sum \text { Deskriptor maksimal }}$}

Hasil perhitungan persentase keberhasilan tindakan pada masing-masing tahapan pembelajaran yang diperoleh akan dibandingkan dengan penentuan skor klasifikasi pada tabel berikut ini.

\section{Tabel 1. Penentuan Skor Klasifikasi Observasi}

\begin{tabular}{ll}
\hline Persentase Keberhasilan Tindakan & Taraf Keberhasilan \\
\hline $85 \%-100 \%$ & Sangat Baik \\
\hline $70 \%-85 \%$ & Baik \\
\hline $65 \%-70 \%$ & Cukup \\
\hline $50 \%-65 \%$ & Kurang \\
\hline $0 \%-50 \%$ & Sangat Kurang \\
\hline
\end{tabular}

Data hasil tes siswa dianalisis dengan membandingkan persentase ketuntasan belajar secara klasikal pada penerapan model pembelajaran berbasis teks siklus I dan siklus II. Sementara itu, persentase ketuntasan belajar secara klasikal dihitung dengan cara membandingkan jumlah siswa yang mencapai ketuntasan belajar dengan jumlah siswa secara keseluruhan (siswa maksimal) kemudian dikalikan $100 \%$.

Persentase ketuntasan belajar klasikal $=\frac{\sum \text { Deskriptor yang muncul }}{\sum \text { Deskriptor maksimal }} \times 100 \%$

Data hasil dokumentasi yang diperoleh berupa foto-foto selama kegiatan pembelajaran berlangsung. Dokumentasi foto ini digunakan sebagai gambaran konkret aktivitas-aktivitas pembelajaran yang terjadi di dalam kelas.

Skema penerapan strategi listening team dapat dilihat pada gambar 1. Skema menunjukkan bahwa strategi listening team terdiri dari kelompok kecil yang setiap kelompok beranggotakan empat orang dengan peran yang berbeda dan kelompok besar yang terdiri dari empat kelompok. Setelah siswa berdiskusi pada kelompok kecil guru mengelompokkan siswa ke kelompok besar sesuai dengan peran masing- masing siswa. Berikut prosedur strategi listening teams asli dan perubahan (Yunita, 2013). 
Tabel 1 Prosedur strategi listening teams asli dan perubahan

\begin{tabular}{|c|c|}
\hline Strategi Listening Teams Asli & Strategi Listening Teams Perubahan \\
\hline $\begin{array}{l}\text { 1. Siswa dibagi menjadi } 4 \text { kelompok } \\
\text { yaitu penanya, pendukung, } \\
\text { penentang, pember contoh }\end{array}$ & $\begin{array}{l}\text { 1. Siswa dibagi menjadi } 5 \text { kelompok, } \\
\text { yaitu penanya, pro, kontra, pemberi } \\
\text { contoh, dan penyimpul }\end{array}$ \\
\hline $\begin{array}{l}\text { 2. Kelompok penanya mengajukan } \\
\text { minimal dua pertanyaan mengenai isi } \\
\text { dialog interaktif }\end{array}$ & $\begin{array}{l}\text { 2. Kelompok penanya mengajukan } \\
\text { minimal dua pertanyaan mengenai isi } \\
\text { dialog interaktif. Penanya diambil dari } \\
\text { kelompok penanya dan guru. }\end{array}$ \\
\hline $\begin{array}{l}\text { 3. Kelompok penyetuju menyampaikan } \\
\text { hal-hal yang disetujui dalam dialog } \\
\text { interaktif. }\end{array}$ & $\begin{array}{l}\text { 3. Kelompok pro menyampaikan hal-hal } \\
\text { yang disetujui dari dialog interaktif } \\
\text { disertai alasan, didasarkan informasi } \\
\text { dialog maupun informasi tambahan dari } \\
\text { membaca surat kabar (internet) }\end{array}$ \\
\hline $\begin{array}{l}\text { 4. Kelompok penentang menyampaikan } \\
\text { hal-hal yang tidak disetujui dari isi } \\
\text { dialog interaktif }\end{array}$ & $\begin{array}{l}\text { 4. Kelompok kontra menyampaikan hal- } \\
\text { hal yang tidak disetujui dari isi dialog } \\
\text { interaktif disertai alasan. }\end{array}$ \\
\hline \multirow[t]{3}{*}{$\begin{array}{l}\text { 5. Kelompok pemberi contoh } \\
\text { memberikan contoh atau penerapan } \\
\text { isi dialog interaktif. }\end{array}$} & $\begin{array}{l}\text { 5. Kelompok pemberi contoh memberikan } \\
\text { contoh atau penerapan isi dialog } \\
\text { disertai alasan. }\end{array}$ \\
\hline & $\begin{array}{l}\text { 6. Tiap kelompok menjawab pertanyaan } \\
\text { kelompok penanya maupun guru } \\
\text { disertai alasan berdasarkan isi dialog } \\
\text { interaktif maupun informasi lainnya. }\end{array}$ \\
\hline & $\begin{array}{l}\text { 7. Kelompok penyimpul menyampaikan } \\
\text { simpulan tugas kelompok pro, kontra, } \\
\text { pemberi contoh sekaligus pertanyaan- } \\
\text { pertanyaan yang diajukan terkait isi } \\
\text { dialog interaktif. }\end{array}$ \\
\hline
\end{tabular}

Adapun langkah kerja penerapan strategi listening team sebagai berikut:

1. Guru membagi siswa ke dalam beberapa kelompok, setiap kelompok beranggotakan empat orang. Setiap anggota kelompok memiliki tugas atau peran yang berbeda sebagai penanya, penjawab, pembantah, dan penarik kesimpulan.

2. Guru memberikan LKS.

3. Guru menjelaskan materi pokok yang akan diajarkan.

4. Guru menyuruh siswa untuk mendiskusikan LKS di dalam kelompok dan mempersiapkan peran masing-masing.

5. Guru mengelompokkan kembali siswa sesuai dengan peran yang telah ditentukan menjadi lima tim.

6. Guru menunjuk siswa secara acak untuk melaksanakan peran dan tugasnya.

7. Guru bersama siswa menyimpulkan materi.

8. Guru memberikan evaluasi berupa tes soal. 


\section{HASIL DAN BAHASAN}

\section{Hasil Penerapan Strategi Listening Teams pada Siklus I}

Tahap pertama yang dilakukan dalam penelitian tindakan kelas siklus I adalah perencanaan. Setelah obseravsi dan menemukan permasalahan dalam pembelajaran di kelas VII SMPN 1 Karangploso, peneliti bekerjasama dengan kolaborator mengatasi masalah yang terjadi pada kegiatan pratindakan.

Merencanakan perbaikan pembelajaran memahami isi teks berarti termasuk di dalamnya merencanakan tindakan dengan melihat kondisi siswa, skenario pembelajaran dari awal sampai akhir dan menyiapkan segala sesuatu yang diperlukan dalam pelaksanaan pembelajaran. Adapun hasil dari perencanaan siklus pertama meliputi (1) peneliti dan kolaborator mengetahui kondisi pembelajaran bahasa Indonesia di SMPN 1 Karangploso, (2) peneliti dan kolaborator mempunyai persamaan persepsi terhadap permasalahan yang ada dalam pembelajaran memahami isi teks di kelas VII SMPN 1 Karangploso, (3) penyebab terjadinya permasalahan dalam kegiatan pembelajaran menyimak dialog interaktif telah teridentifikasi dengan baik oleh peneliti dan kolaborator, (4) peneliti bersama kolaborator merancang pelaksanaan pemecahan masalah dalam pembelajaran memahami isi teks.

Melihat dari kondisi siswa dan permasalahan yang ada di kelas, peneliti dan kolaborator memutuskan untuk mencoba menggunakan strategi listening teams yang diyakini akan membawa perubahan dalam pembelajaran, (5) peneliti dan kolaborator menetapkan waktu pelaksanaan penelitian tindakan kelas siklus I, (6) peneliti dan kolaborator membuat skenario kegiatan pembelajaran yang meliputi skenario pelaksanaan tindakan dan persiapan media pembelajaran. Peneliti dan kolaborator menentukan tindakan yang dilakukan dan menyiapkan video, rekaman, atau bacaan yang digunakan dalam pembelajaran, (7) pembentukan kelompok sesuai dengan aturan dalam strategi listening teams. Ada lima kelompok yang terbentuk, kelompok pertama berperan sebagai kelompok pro, kelompok kedua berperan sebagai kelompok kontra, kelompok ketiga berperan sebagai kelompok pemberi contoh, kelompok keempat berperan sebagai kelompok penyimpul, kelompok kelima sebagai penanya, (8) peneliti menyiapkan instrumen penelitian berupa catatan lapangan, lembar pengamatan.

\section{Pelaksanaan Siklus I}

Pelaksanaan diawali dengan pendahuluan berupa salam, doa, apersepsi, dan penyampaian tujuan pembelajaran. Guru menjelaskan kepada siswa mengenai materi pelajaran menyimak dialog interaktif dan strategi listening teams serta membagi siswa menjadi lima kelompok. Dalam satu kelompok terdiri dari 5-6 siswa. Anggota kelompok telah ditentukan sebelumnya oleh peneliti pada kegiatan perencanaan. Kelompok pro terdiri dari siswa S1 sampai S6, kelompok kontra terdiri dari siswa S7 sampai S12, kelompok pemberi contoh terdiri dari siswa S13 sampai S18, dan kelompok penyimpul terdiri dari siswa S19 sampai S23, dan kelompok penanya terdiri dari siswa S24 sampai S28. Berikut penyajian pembagian kelompok beserta tugas tiap kelompok. 
CENDEKIA, Vol. 11, No. 2, Oktober 2017

p ISSN: 1978 2098; e ISSN: 2407 8557

Http://cendekia.pusatbahasa.or.id; Email: cendekiaoslo@gmail.com

Center of Language and Culture Studies, Surakarta, Indonesia

Handayani, Sri. 2017. Listening Teams: Strategi Pemahaman Isi Teks

Pada Siswa SMPN 1 Karangploso. Cendekia, (2017), 11(2): 129 142.

Tabel 2. Pembagian Tugas Kelompok Menggunakan Strategi Listening Teams

\begin{tabular}{|c|c|c|}
\hline Siswa & Kelompok & Tugas \\
\hline S1 & \multirow[t]{6}{*}{ Pro } & \multirow{6}{*}{$\begin{array}{l}\text { Kelompok pro menyampaikan hal-hal apa saja yang } \\
\text { disetujui dari dialog interaktif yang dibacakan disertai } \\
\text { alasan, baik dari dialog interaktif yang dibacakan } \\
\text { maupun informasi dari luar. }\end{array}$} \\
\hline S2 & & \\
\hline S3 & & \\
\hline S4 & & \\
\hline S5 & & \\
\hline S6 & & \\
\hline S7 & & \\
\hline S8 & & \\
\hline S9 & \multirow[t]{8}{*}{ Kontra } & \multirow{8}{*}{$\begin{array}{l}\text { Kelompok kontra menyampaikan hal-hal apa saja yang } \\
\text { tidak disetujui/ditentang dari dialog interaktif yang } \\
\text { dibacakan disertai alasan, baik dari dialog interaktif } \\
\text { yang dibacakan maupun informasi dari luar. }\end{array}$} \\
\hline S10 & & \\
\hline S11 & & \\
\hline $\mathrm{S} 12$ & & \\
\hline $\mathrm{S} 13$ & & \\
\hline S14 & & \\
\hline S15 & & \\
\hline S16 & & \\
\hline S17 & \multirow[t]{7}{*}{ Pemberi contoh } & \multirow{7}{*}{$\begin{array}{l}\text { Kelompok pemberi contoh memberikan contoh atau } \\
\text { penerapan khusus dari isi dialog interaktif yang } \\
\text { dibacakan disertai alasan, baik dari dialog interaktif } \\
\text { yang dibacakan maupun informasi dari luar. }\end{array}$} \\
\hline S18 & & \\
\hline S19 & & \\
\hline S20 & & \\
\hline S21 & & \\
\hline S22 & & \\
\hline S23 & & \\
\hline S24 & \multirow[t]{6}{*}{ Penyimpul } & \multirow{6}{*}{$\begin{array}{l}\text { Kelompok penyimpul menyampaikan kesimpulan dari } \\
\text { penyampaian tugas kelompok penyetuju, penentang, } \\
\text { pemberi contoh, dan jawaban atas pertanyaan } \\
\text { kelompok penanya mengenai isi dialog interaktif yang } \\
\text { dibacakan. }\end{array}$} \\
\hline S25 & & \\
\hline S26 & & \\
\hline S27 & & \\
\hline S28 & & \\
\hline S29 & & \\
\hline S30 & \multirow[t]{5}{*}{ Penanya } & \multirow{5}{*}{$\begin{array}{l}\text { Kelompok penanya menanyakan minimal } 2 \\
\text { pertanyaan mengenai isi dialog interaktif yang telah } \\
\text { dibacakan }\end{array}$} \\
\hline S31 & & \\
\hline S32 & & \\
\hline S33 & & \\
\hline S34 & & \\
\hline
\end{tabular}

Setelah pembagian kelompok selesai dan siap, pembacaan teks bacaan yang telah disiapkan sebanyak tiga kali. Semua siswa mencatat isi teks yang dibacakan ke dalam buku catatan. Kegiatan pembelajaran masuk pada tahap pelaksanaan strategi listening teams. Sebelum siswa berdiskusi, kelompok penanya memberikan dua pertanyaan kepada semua kelompok mengenai isi dialog interaktif. Siswa melakukan kegiatan diskusi selama 20 menit untuk membahas isi teks sesuai dengan tugas masingmasing kelompok. 
Setelah siswa selesai berdiskusi, setiap kelompok mengutarakan hasil diskusi di depan kelas sesuai dengan tugasnya masing-masing. Pengutaraan hasil diskusi dimulai dari kelompok pro. Kelompok pro memaparkan jawaban pertanyaan dari kelompok penanya dan hasil diskusi mereka yang menyatakan bahwa mereka setuju dengan isi teks. Setelah selesai memaparkan hasil diskusi, guru yang berperan sebagai penengah memberikan kesempatan kepada kelompok lain untuk memberikan pertanyaan atau tanggapan. Pemaparan jawaban pertanyaan kelompok penanya dan hasil diskusi kemudian dilanjutkan oleh kelompok kontra dan guru kembali menjadi penengah, begitu pula dengan kelompok pemberi contoh dan penyimpul. Kegiatan ini dilakukan untuk mengetahui sejauh mana kemampuan siswa dalam memahami bacaan.

Pada akhir pembelajaran guru bersama siswa merefleksi materi pelajaran dan strategi pembelajaran yang telah dilakukan serta memberi penjelasan kepada siswa mengenai hal apa saja yang menjadi kekurangan saat proses pembelajaran berlangsung. Guru menginformasikan kepada siswa bahwa pada pertemuan berikutnya dilaksanakan tes kemampuan menyimak dialog interaktif berdasarkan kegiatan pembelajaran yang sudah dilakukan.

Tes dilaksanakan kurang lebih dalam waktu 60 menit. Pada saat pengerjaan soal, beberapa siswa masih terlihat kesulitan dalam mengerjakan soal karena soal dikerjakan secara individu. Setelah semua siswa selesai mengerjakan soal, guru langsung meminta semua siswa untuk mengumpulkan hasil tes dan menutup pelajaran.

Pengamatan dilakukan dengan melihat dari dua segi, yakni dari segi hasil dan segi proses. Dari hasil pengamatan yang dilakukan, dilihat dari segi hasil terjadi peningkatan skor rata-rata kelas dari kegiatan pratindakan ke siklus pertama dan tercapainya beberapa indikator keberhasilan yakni 1) skor rata-rata kelas pada kegiatan pratindakan ialah sebesar 67,29 dan pada siklus pertama skor rata-rata kelas meningkat menjadi 73,32 ; 2) siswa mampu menjawab pertanyaan teks; 3) siswa mampu memaknai kata/istilah; 4) siswa mampu menyimpulkan isi teks. Rata-rata skor kelas mengalami peningkatan sekitar $6,03 \%$ dari hasil prasiklus 67,29 dan setelah melakukan pembelajaran dengan strategi listening teams siklus I meningkat menjadi 73,32. Pada prasiklus, siswa yang tuntas belajar hanya 7 siswa (20,59\%), sedangkan siswa yang belum tuntas 27 siswa $(79,41 \%)$. Setelah tindakan siklus I, siswa yang tuntas belajar meningkat 18 siswa (52,94\%), sedangkan yang belum tuntas 16 siswa $(47,06 \%)$.

Sementara itu, segi proses pembelajaran mengalami peningkatan. Catatan lapangan dan angket siswa menunjukkan lima indikator aktivitas siswa mengalami kenaikan. Keberhasilan memahami isi teks terdiri atas lima indikator, meliputi menjawab pertanyaan, memaknai kata/istilah, menyimpulkan isi teks, mendiskusikan isi teks, dan menyimpulkan hasil diskusi.

Berdasarkan tabel 3 diketahui terdapat peningkatan pada keseluruhan indikator menyimak dialog interaktif. Peningkatan indikator 1 sebesar $17,65 \%$ berdasarkan prasiklus 18 siswa $(52,94 \%)$ yang mampu menjawab pertanyaan, sedangkan siklus I meningkat menjadi 24 siswa (70,59\%). Indikator memaknai istilah/kata pada prasiklus hanya 20 siswa (58,82\%), sedangkan siklus I meningkat menjadi 76,47\% atau 26 siswa. Indikator menyimpulkan isi teks pada prasiklus hanya 19 siswa $(55,88 \%)$, sedangkan siklus I meningkat menjadi 24 siswa (70,59\%). 
CENDEKIA, Vol. 11, No. 2, Oktober 2017

p ISSN: 1978 2098; e ISSN: 2407 8557

Http://cendekia.pusatbahasa.or.id; Email: cendekiaoslo@gmail.com Center of Language and Culture Studies, Surakarta, Indonesia

Handayani, Sri. 2017. Listening Teams: Strategi Pemahaman Isi Teks

Pada Siswa SMPN 1 Karangploso. Cendekia, (2017), 11(2): 129 142.

Tabel 3 Hasil Peningkatan Proses Pembelajaran

\begin{tabular}{|l|l|c|c|c|c|}
\hline \multirow{2}{*}{ No } & \multicolumn{2}{|c|}{ Indikator Keberhasilan } & \multicolumn{4}{|c|}{ Jumlah siswa } \\
\cline { 3 - 6 } & & Prasiklus & $\%$ & Siklus & $\%$ \\
\hline 1. & Mampu menjawab pertanyaan & 18 & 52,94 & 24 & 70,59 \\
\hline 2. & Mampu memaknai kata/istilah & 20 & 58,82 & 26 & 76,47 \\
\hline 3. & Mampu menyimpulkan isi teks & 19 & 55,88 & 24 & 70,59 \\
\hline 4. & Mampu mendiskusikan isi teks & 22 & 64,71 & 25 & 73,53 \\
\hline 5. & Mampu menyimpulkan hasil diskusi & 21 & 61,76 & 25 & 73,53 \\
\hline
\end{tabular}

Indikator mendiskusikan isi teks pada prasiklus ada 22 siswa $(64,71 \%)$, sedangkan siklus I meningkat menjadi 25 siswa (73,53\%). Indikator menyimpulkan hasil diskusi kelompok pada prasiklus hanya 21 siswa (61,76\%), sedangkan siklus I meningkat menjadi 25 siswa $(73,53 \%)$. Hal ini menunjukkan ada beberapa indikator yang belum tuntas, meliputi 1) sebagian siswa belum mampu menjawab pertanyaan, 2) beberapa siswa belum mampu menyimpulkan isi teks, 3) sebagian siswa belum mampu mendiskusikan isi teks dalam kelompok, 4) sebagian siswa belum mampu menentukan simpulan hasil diskusi kelompok

Berdasarkan catatan lapangan, ada beberapa peningkatan terkait sikap siswa, meliputi 1) siswa menunjukkan antusias dalam pembelajaran memahami isi teks mengggunakan strategi listening teams, 2) sikap dan motivasi siswa mengalami peningkatan, 3) dalam diskusi kelompok, sebagian siswa berani mengeluarkan pendapat dan gagasan, 4) dalam penggunaan strategi listening teams siswa mengasah kemampuan memahami bacaan.

Kegiatan refleksi dilakukan oleh peneliti dan observer. Pelaksanaan pembelajaran memahami isi teks siklus I menggunakan strategi listening teams berjalan dengan cukup lancar. Namun, pelaksanaan pada siklus I ini belum menampakkan hasil yang memuaskan. Hal ini terlihat dari hasil tes siswa yang skor rata-rata kelas masih belum mencapai ketuntasan 75 . Selain itu, indikator keberhasilan pada segi hasil belum tercapai secara keseluruhan. Berdasarkan segi proses, hasil belum sesuai dengan yang diharapkan. Beberapa siswa masih terlihat sulit berkonsentrsai karena gangguan dari dalam dan luar kelas, serta masih malu bertanya dan mengemukakan pendapat.

Permasalahan yang terjadi pada siklus pertama ini telah didiskusikan peneliti dan observer dalam kegiatan refleksi untuk menemukan penyelesaian. Penyelesaian masalah tersebut dengan meningkatkan perhatian dan konsentrasi siswa. Selain itu, diadakan perubahan media dalam penyampaian bacaan yakni dengan menggunakan teks berupa teks berita yang didownload dari internet, serta pergantian kelompok dalam strategi listening teams agar siswa lebih memahami kekurangannya.

\section{Hasil Penerapan Strategi Listening Teams pada Siklus II}

Penerapan strategi listening teams dalam pembelajaran memahami isi teks pada siklus II dilaksanakan sama dengan siklus I. Perbedaan terletak pada penggunaan media dan isi teks bacaan. Pengamatan dilakukan dengan melihat dari dua segi, yakni dari segi hasil dan segi proses. Dari hasil pengamatan yang dilakukan, dilihat dari segi hasil terjadi peningkatan skor rata-rata kelas dari kegiatan pratindakan ke siklus pertama dan tercapainya beberapa indikator keberhasilan, yakni 1) skor rata-rata kelas pada kegiatan 
siklus I sebesar 73,32 sedangkan pada siklus II skor rata-rata kelas meningkat menjadi $82,35 ; 2)$ ketuntasan belajar kelas telah tercapai $\geq 75$ karena siswa yang tuntas belajar ada 28 siswa $(85 \%)$.

Berdasarkan proses pembelajaran terjadi peningkatan pada siswa, meliputi 1) siswa menunjukkan antusias yang cukup tinggi dalam pembelajaran memahami isi teks dengan mengggunakan strategi listening teams, 2) sikap dan motivasi siswa meningkat, 4) dalam diskusi kelompok, siswa berani berpendapat, 5) dalam penggunaan strategi listening teams siswa mengasah kemampuan dalam memahami isi teks. Peningkatan indikator 1 berdasarkan siklus I terdapat 24 siswa (70,59\%), sedangkan siklus II meningkat menjadi 26 siswa (76,47\%). Indikator memaknai istilah/kata pada siklus I $76,47 \%$ atau 26 siswa, sedangkan siklus II menjadi 28 siswa (82,35\%). Indikator menyimpulkan isi teks pada siklus I terdapat 24 siswa (70,59\%), sedangkan siklus II menjadi 29 siswa $(85,29 \%)$. Indikator mendiskusikan isi teks pada siklus I 25 siswa (73,53\%), sedangkan siklus II menjadi 27 siswa $(79,41 \%)$. Indikator menyimpulkan hasil diskusi kelompok pada siklus I terdapat 25 siswa $(73,53 \%)$, sedangkan siklus II meningkat menjadi 26 siswa $(76,47 \%)$.

Pada siklus kedua masih terdapat beberapa kekurangan. Kekurangan tersebut didasarkan dari lembar pengamatan dan catatan lapangan meliputi, 1) tiga siswa masih sulit konsentrasi dalam menyimak dialog interaktif, 2) tiga siswa enggan berdiskusi dan hanya diam. Dalam tahap ini, kegiatan refleksi dilakukan oleh peneliti dan observer. Pelaksanaan pembelajaran memahami isi teks siklus II menggunakan strategi listening teams berjalan lancar. Hasil pencapaian skor rata-rata siswa telah mencapai ketuntasan. Hal ini terlihat dari hasil tes siswa yang skor rata-rata kelas 82,35 atau $\geq 75$. Berdasarkan segi proses, diskusi dapat dilaksanakan karena siswa berada dalam kelompok masing-masing dan bekerja sesuai dengan peran dalam kelompok. Siswa yang masih kesulitan konsentrasi menyimak hanya 2 siswa, ada 3 siswa yang enggan berdiskusi.

\section{BAHASAN}

Berdasarkan hasil penelitian, baik pada tindakan kelas siklus I dan siklus II dengan menggunakan straegi listening teams dapat dikatakan terjadi peningkatan kemampuan memahami isi teks pada siswa kelas VII SMP Negeri 1 Karangploso. Dengan menggunakan strategi listening teams siswa lebih memahami materi pelajaran seperti isi teks, menulis simpulan teks, dan menjawab pertanyaan. Hal tersebut dibuktikan dengan tercapainya indikator keberhasilan yang telah dirumuskan dalam penelitian, peningkatan skor rata-rata kelas tiap tindakan berdasarkan hasil tes menyimak, dan beberapa hambatan yang dapat diselesaikan selama proses pembelajaran memahami isi teks bacaan.

Berdasarkan grafik 1, diketahui ketuntasan belajar memahami isi teks terus meningkat. Prasiklus siswa yang tuntas hanya $17,86 \%$, sedangkan siklus II naik menjadi $42,86 \%$ dan siklus II mencapai $85,72 \%$. Siswa yang belum tuntas belajar mengalami penurunan dari prasiklus hingga siklus II. Pada prasiklus ketidaktuntasan mencapat $82,14 \%$, sedangkan siklus I menurun menjadi $57,14 \%$, dan pada siklus II hanya $14,28 \%$. Hal ini membuktikan bahwa penggunaan strategi listening teams berhasil diterapkan dalam pembelajaran memahami isi teks. 


\section{Grafik 1 Peningkatan Hasil Belajar Memahami Isi Teks Menggunakan Strategi Listening Teams}

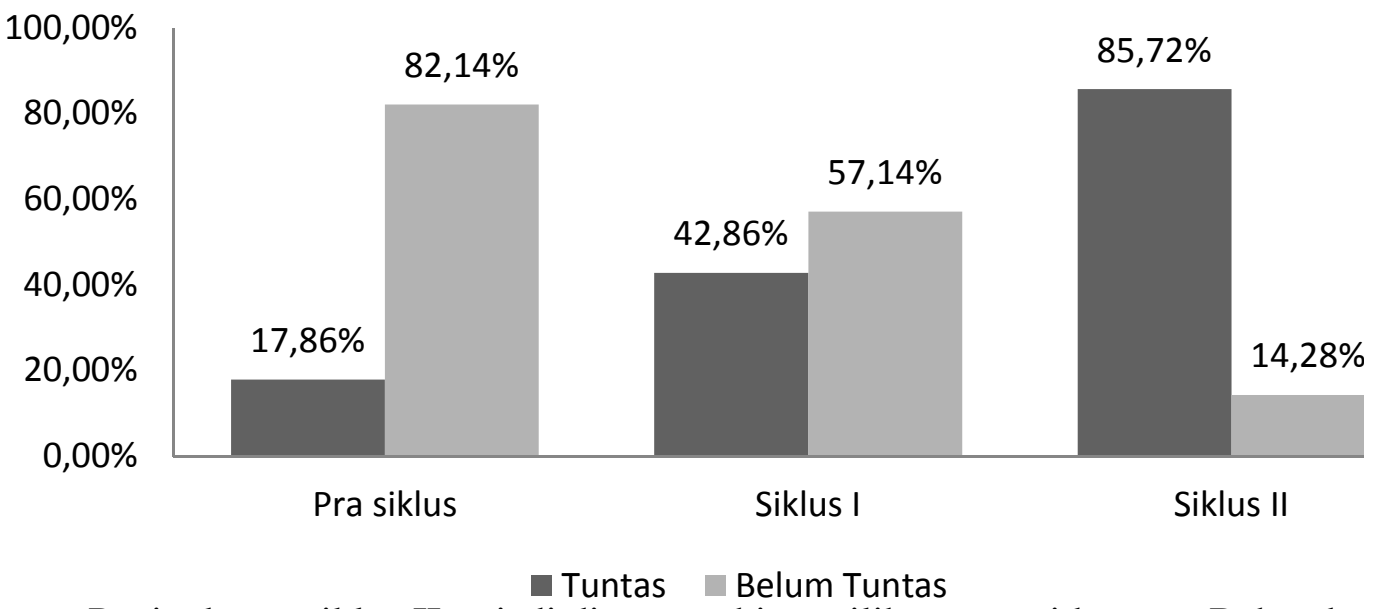

Peningkatan siklus II terjadi dipengaruhi pemilihan materi bacaan. Bahan bacaan yang menarik membuat siswa fokus membaca. Nurgiyantoro (2001:234) menyatakan bahwa untuk tes kemampuan membaca, pemilihan bahan tes ditekankan pada keadaan wacana, baik dilihat dari segi tingkat kesulitan, isi dan cakupan, maupun jenis-jenis wacana. Selain itu, rangsang audiovisual memberikan motivasi siswa dalam proses pembelajaran sehingga hasil tes menyimak pun meningkat. Aktivitas kelompok meningkat dilihat dari prasiklus, siklus I, dan siklus II. Peningkatan tersebut dipengaruhi tingkat pemahaman siswa terhadap strategi listening teams. Siswa telah berperan sesuai dengan tanggung jawabnya di dalam kelompok. Strategi listening teams merupakan kelompok-kelompok kecil yang bertanggungjawab untuk mengklarifikasi materi pelajaran (Silberman, 2012:121).

\section{SIMPULAN}

Berdasarkan hasil penelitian dan pembahasan yang telah diuraikan, dapat disimpulkan beberapa hal sebagai berikut.

1. Pelaksanaan pembelajaran memahami isi teks menggunakan strategi listening teams pada siswa kelas VII SMPN 1 Karangploso berjalan dengan lancar. Dari segi hasil, terjadi peningkatan kemampuan memahami isi teks pada siswa dengan meningkatnya jumlah siswa pada masing-masing indikator keberhasilan dari prasiklus hingga siklus II.

2. Peningkatan kemampuan memahami isi teks menggunakan strategi listening teams dapat dilihat melalui skor rata-rata kelas mulai dari kegiatan prasiklus hingga siklus II. Ketuntasan belajar memahami isi teks terus meningkat. Prasiklus siswa yang tuntas hanya $17,86 \%$, sedangkan siklus II naik menjadi $42,86 \%$ dan siklus II mencapai $85,72 \%$. Siswa yang belum tuntas belajar mengalami penurunan dari prasiklus hingga siklus II. Pada prasiklus ketidaktuntasan mencapat $82,14 \%$, sedangkan siklus I menurun menjadi $57,14 \%$, dan pada siklus II hanya 14,28\%. Hal ini membuktikan bahwa 
penggunaan strategi listening teams berhasil diterapkan dalam pembelajaran memahami isi teks. Selain itu, peningkatan kemampuan memahami isi teks juga terlihat dari aktivitas siswa dalam proses pembelajaran yang lebih baik dari kegiatan prasiklus hingga siklus II, seperti siswa terlihat sudah lebih berani bertanya, berani mengeluarkan pendapat, berani menjawab pertanyaan, serta terlihat lebih aktif dan antusias dalam pembelajaran.

\section{SARAN}

Berdasarkan hasil simpulan penelitian dapat diajukan saran sebagai berikut.

\section{Bagi Guru}

Strategi pembelajaran aktif listening teams yang digunakan dalam penelitian ini dapat memberikan masukan bagi guru mata pelajaran bahasa Inggris sebagai salah satu strategi alternatif dalam pembelajaran memahami isi teks atau pembelajaran lainnya.

2. Bagi Siswa

Siswa lebih aktif dan antusias dalam mengikuti pembelajaran dengan menggunakan strategi listening teams.

3. Bagi Sekolah

Pihak sekolah harus lebih memperhatikan dan memantau kegiatan pembelajaran di kelas agar kualitas tenaga pendidik dan siswa menjadi lebih baik.

\section{DAFTAR PUSTAKA}

Dimyati dan Mudjiono. 2009. Belajar dan Pembelajaran. Jakarta: Rineka Cipta.

Lubis, M. Iqbal. Pengaruh Model Pembelajaran Kooperatif Listening Team Terhadap Pemahaman Siswa Di Sekolah Menengah Atas Negeri 1 Kuantan Singingi. (online)

Nurhadi, 2002 Pendekatan Kontekstual (Contextual Teaching and Learning). Malang: Universitas Negeri Malang.

Nurgiyantoro, Burhan. 2001. Penilaian dalam Pengajaran Bahasa dan Sastra. Yogyakarta: BPFE.

Nurgiyantoro, Burhan. 2010. Penilaian Pembelajaran Bahasa Berbasis Kompetensi. Yogyakarta: BPFE.

Silberman, Melvin. 2012. Active Learning (101 Cara Siswa Belajar Aktif). Nuansa: Bandung.

Sudijono, Anas. 2008. Pengantar Evaluasi Pendidikan. PT Raja Grafindo Persada: Jakarta.

Tarigan, Henry Guntur. 1980. Membaca sebagai Suatu Keterampilan Berbahasa. Bandung: Angkasa.

Wiriaatmadja, Rochiati. 2007. Metode Penelitian Tindakan Kelas. Bandung: PT Remaja Rosdakarya.

http://ejournal.unp.ac.id/index.php/isla/article/download/3962/3193 
CENDEKIA, Vol. 11, No. 2, Oktober 2017

p ISSN: 1978 2098; e ISSN: 2407 8557

Http://cendekia.pusatbahasa.or.id; Email: cendekiaoslo@gmail.com

Center of Language and Culture Studies, Surakarta, Indonesia

Handayani, Sri. 2017. Listening Teams: Strategi Pemahaman Isi Teks

Pada Siswa SMPN 1 Karangploso. Cendekia, (2017), 11(2): 129 142.

Sanjaya, Wina. 2009. Kurikulum dan Pembelajaran: Teori dan Praktek Pengembangan Kurikulum Tingkat Satuan Pendidikan (KTSP). Jakarta: Kencana.

http://edukasi.kompas.com/read/2016/08/29/07175131/minat.baca.indonesia.ada.di.urut an.ke-60.dunia

Yunita, Meli. 2013. Peningkatan Kemampuan Menyimak Berita dengan Menggunakan Strategi Listening Teams pada Siswa Kelas VII SMPN 2 Kalasan Yogyakarta. (Online).

Zaini, Hisyam dkk. 2011. Strategi Pembelajaran Aktif. Yogyakarta: CTSD. 